\title{
An Indicator-Based Approach to Assess the Readiness of Urban Forests for Future Challenges: Case Study of a Mediterranean Compact City
}

\author{
$M^{a}$ Fernanda Maradiaga-Marín ${ }^{1}$ and Paloma Cariñanos $1,2, *$ (D) \\ 1 Department of Botany, University of Granada, 18071 Granada, Spain; mfmaradiaga@correo.ugr.es \\ 2 Andalusian Institute for Earth System Research (IISTA-CEAMA), University of Granada, \\ 18071 Granada, Spain \\ * Correspondence: palomacg@ugr.es
}

Citation: Maradiaga-Marín, M.F.; Cariñanos, P. An Indicator-Based

Approach to Assess the Readiness of Urban Forests for Future Challenges: Case Study of a Mediterranean Compact City. Forests 2021, 12, 1320 https://doi.org/10.3390/f12101320

Academic Editors:

Manuel Esperon-Rodriguez and Tina Harrison

Received: 18 August 2021

Accepted: 24 September 2021

Published: 27 September 2021

Publisher's Note: MDPI stays neutral with regard to jurisdictional claims in published maps and institutional affiliations.

Copyright: (C) 2021 by the authors. Licensee MDPI, Basel, Switzerland. This article is an open access article distributed under the terms and conditions of the Creative Commons Attribution (CC BY) license (https:// creativecommons.org/licenses/by/ $4.0 /)$.

\begin{abstract}
Urban Forests (UFs) are key elements in Mediterranean compact cities, as they provide numerous ecosystem benefits and increase the resilience of cities against the anticipated impacts of climate change. It is, thus, necessary to review all the aspects that may have a negative effect on their ecosystem functions and the services that they provide. In this paper, a set of indicators is proposed that allow for a preliminary evaluation of some of the main disservices and factors that Mediterranean UFs present and the ways to maximize their benefits for users. For this purpose, 20 indicators, divided into three categories-Biodiversity, Accessibility/Facilities, and Infrastructurewere selected. Within these three categories, a range of values was established, from low to high or absence/presence. The indicators were tested in 24 urban forests of different types, all of which are representative of a medium-sized compact Mediterranean city. The results highlight that the UFs have adequate species richness and diversity, but among the species present are quite a few that emit BVOCs and allergens, as well as some that have invasive behavior. Poor cleaning, absence of night lightning, and scarcity of water points are aspects to improve in a good number of UFs; while a high surface area of impermeable soil, low tree cover, and extensive areas of grass that require large amounts of water for maintenance are the main issues of the infrastructure block that need medium-term planning to be addressed. It can be concluded that the proposed set of indicators allows for a general assessment of the readiness of UFTs in Mediterranean cities for the upcoming climatic, social, and ecological challenges.
\end{abstract}

Keywords: ecosystem disservices; Mediterranean region; green infrastructure; urban forest types; indicators

\section{Introduction}

An urban forest (UF) can be described as all the trees and wooded areas in an urban space. This includes both public and private spaces, such as parks and gardens, and alongside streets, homes, and schools. Overall, UFs improve the urban ecosystem and increase recreational value, so they can be considered as key elements in the interconnected network that forms urban green infrastructure (UGI) [1,2]. As integral components of urban ecosystems, UFs provide a variety of Ecosystem Services (ES) [3-5]. Moreover, they bolster urban connectivity [6] and social cohesion and integration [7], provide shelter in situations of risk and natural disasters [8], and have been fundamental elements of physical and mental health restoration during the COVID-19 pandemic [9]. Given the significant impact that climate change can have in some areas of the world, UFs also stand out as one of the most efficient measures for strengthening climate resilience in cities [10]. Hence, increasing and reinforcing urban greening is one of the main solutions being implemented in municipalities to mitigate and adapt to the effects of climate change [11]. However, this process of greening cities may be slowed down by the urban, socio-cultural, and structural limitations 
of each territory. Thus, in densely populated cities it may be difficult to find areas to develop new green spaces. In this way, already existing UFs must be prepared for the current and future environmental, social, economic, and cultural challenges, so that they can guarantee the population access to high-quality spaces that improve life quality.

The Mediterranean region is currently one of the most urbanized areas in the world and has some of the fastest urbanization rates. With growth rates of most major cities between $1.5 \%$ and $2 \%$ per year [12], the current percentage of the population that live in cities $(55 \%)$ is expected to increase to $68 \%$ by 2050 , testing the capacity of Mediterranean cities to manage growth $[13,14]$. Additionally noteworthy is the lack of a sustainable urban development model to anticipate rapid population growth, which is causing a densified and extended urbanization towards the periphery. However, above all, this growth is causing a change in the traditional characteristic compact growth [15]. A problem related to this high urban densification is the lack of available space for the implementation of green areas [16]. The use of any available surface as buildable land or the extension of the city to the (sometimes scarce) peripheral natural areas is causing not only losses in terms of available green surface, but also making it difficult for certain social sectors to access UFs [17]. Furthermore, the scarcity of green areas is characteristic of many Mediterranean compact cities, since many of these cities have low per capita green space [18]. This situation highlights that, given the difficulty of finding areas for the implementation of new UFs, the planning and management of existing ones must be prioritized to maximize the ecosystem functions they are providing.

It is common for many Mediterranean cities to have prioritized cultural and tourism infrastructure when designing and planning new urban green spaces [19]. The Mediterranean climate, which is characterized by mild temperatures for many months of the year and an amount of sunshine greater than $2500 \mathrm{~h}$ /year, favors many outdoor activities [20], with UFs being the center of positive social, intercultural, and intergenerational interactions that cultivate social cohesion in ways that enhance health and well-being [7]. The rich historical and cultural heritage of Euro-Mediterranean cities can also be seen in the high number of Historic Gardens and other Green Spaces of different Mediterranean countries in the UNESCO World Heritage Cultural Landscapes program [21]. However, there are other relevant aspects that have not received the same attention, and that in one way or another affect both the quality of these spaces and the benefits to the population, as well as a positive net balance of ecosystem services. For various reasons (aesthetic, traditional) or due to lack of planning, UFs have been the entry point for pests and diseases that threaten biodiversity [22]. They can be the origin for the expansion of invasive species [23] or the source of the emission of compounds (BVOCs and allergens) with an impact on health $[24,25]$. Frequently, the bioclimatic characteristics of the Mediterranean climate have not been considered when designing thermal comfort spaces [26] or selecting plant species with water requirements compatible with local species [27]. On other occasions, the scarcity of equipment and services, the absence of facilities for vulnerable groups, or impediments to accessibility to the space are some of the factors that affect user satisfaction [28]. Thus, a review of all these aspects that can negatively impact the balance of ecosystem services provided by UFs in Mediterranean cities is necessary.

Monitoring the ecosystem services provided by urban forests through indicators is one of the best ways to quantify and value the capacity of natural processes and components to provide goods and services that satisfy human needs [29]. Some authors have highlighted how this provisioning capacity is variable according to a series of structural, morphological, location, scale, and management factors. These factors are related both to urban forests themselves and to the urban environment [30,31]. The incorporation of indicators to measure ecosystem services as an approach for risk assessment or on the impact on human well-being is becoming more frequent $[30,32,33]$. In these proposals, researchers usually use either a single category that groups the different disservices [30] or different categories are established depending on the type of disservice or hazard they cause: Aesthetic, Safety, Health, Economic, and Environmental, among others [34,35]. The impacts caused by 
anthropization in green areas have also been evaluated, and two categories of indicators have been established: conservation indicators and public use indicators [36]. In addition to the indicators to assess ecosystem services, it is also important to add indicators to assess other factors like what the conditions are for the inhabitants who visit these spaces for recreation. The consideration of the benefits that these green spaces can provide would not be complete without considering certain amenities such as lighting, recreational elements, and bathroom facilities, among others [28,37].

Understanding the ecological context and the factors that influence the use and enjoyment of UFs is related to socio-cultural characteristics and needs. Thus, this work aimed to establish a series of indicators of some main disservices and factors that UFs of Mediterranean cities can present, so that they can be used as a preliminary checklist for fine-tuning and improvement needs, and to reinforce the functions and ecosystem services they provide. This work is justified by the significant impact that climate change will have on the Mediterranean region-declared one of the most vulnerable to the effects of increased temperatures and reduced rainfall-as well as the significant changes in city models that are expected in the coming decades, where the shortage of new green areas will continue to increase.

\section{Materials and Methods}

\subsection{Study Area}

The study was carried out in the city of Granada (37.179937, -3.603489; 680 m.a.s.1), located in the southeast of the Iberian Peninsula (Figure 1), which presents the characteristics of the typical model of a medium-sized Mediterranean compact city. These characteristics include a high population density, compact buildings, complex urban uses, the proximity of services on a pedestrian scale, and mixed residential and commercial areas [38,39]. Granada contains a population density of 2654.4 inhabitants $/ \mathrm{km}^{2}\left(233,648\right.$ inhabitants, $88.02 \mathrm{~km}^{2}$ of surface) and a $21.8 \%$ of the population is above 65 years of age [40,41]. Agriculture, commerce, and scientific-technical activities are the main sectors of economic activity [42]. The city is in a wide depression formed by the Genil River and the Sierra Nevada Mountain Range valley and has a continental-Mediterranean climate with an average annual temperature of $15.6^{\circ} \mathrm{C}$ and an annual rainfall of $359 \mathrm{~mm}$ (for the period 1981-2010). The city also has a wide range of thermal amplitude [43]. Granada has been identified as one of the Mediterranean cities showing greater frequency of heat and cold waves [44]. Due to the intensity of traffic in and around the city, and the numerous sources of bioaerosol-type pollen emissions, Granada is currently one of the most polluted cities in Spain by both biotic and abiotic pollutants $[45,46]$.

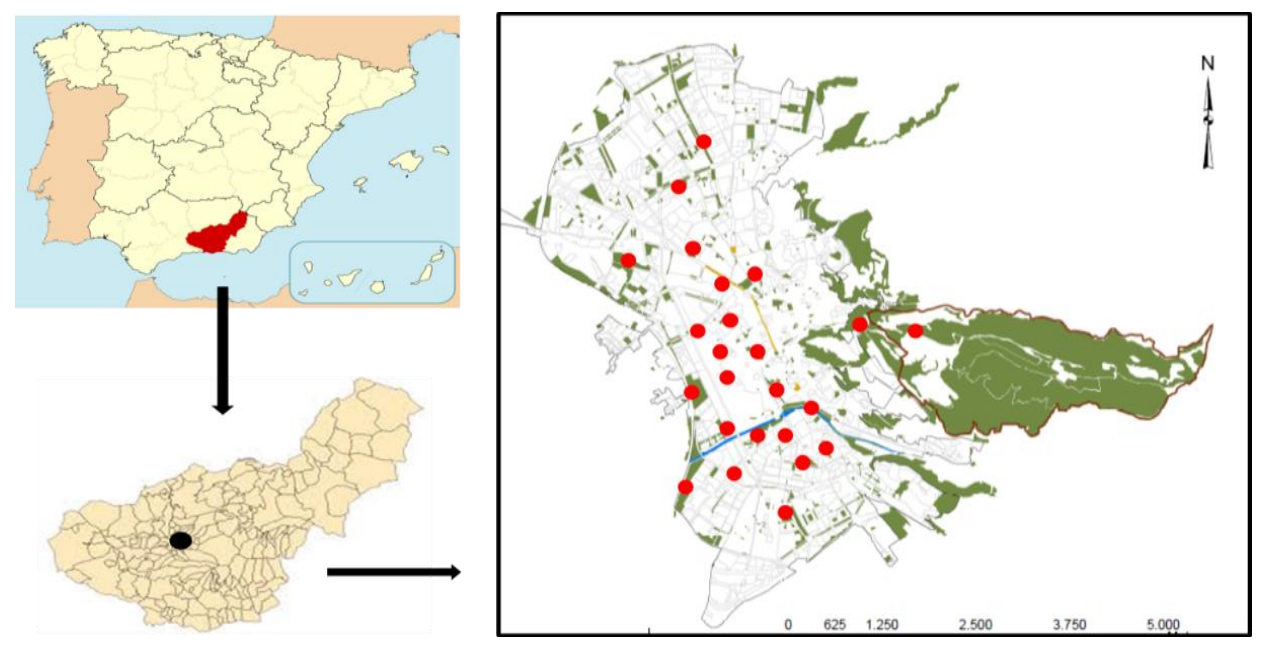

Figure 1. Location of the city of Granada along with the location of the 24 urban green spaces considered in this study [39]. 


\section{Selection of Cases}

According to data provided by the Environmental Information Network of Andalusia (REDIAM), there are 363 registered UFs of different types in the city, although 341 of them $(93.9 \%)$ have a surface area less than $10,000 \mathrm{~m}^{2}$ [38]. The total green surface area is $1,141,884.7 \mathrm{~m}^{2}$, which translates to a public green surface area of $4.9 \mathrm{~m}^{2}$ per inhabitant. For our study, 24 of these UFs with a total area of $543,583 \mathrm{~m}^{2}(47.6 \%$ of the total green area of the city) were considered. The criteria for selecting the urban forests included those that are in public spaces and are mostly managed by the local Administration or, failing that, by other public administrations, so that all aspects related to its management and maintenance were regulated by the same regime. We were also interested in selecting UFs located within residential and commercial neighborhoods, frequently visited by the population and $/ \mathrm{r}$ tourists, due to its historical character, and at the same time can potentially support urban biodiversity and provide recreational services. Finally, we also considered as a criterion that the UFs were representative of compact/historical Mediterranean cities; that is, places in which the typologies city parks, pocket parks, tree-lined streets, boulevards, and plazas are the most abundant.

\subsection{Selection of Indicators}

To check for possible disservices and other factors that UFTs could present, we selected a series of simple measurement indicators-those that can be used by researchers and laypeople alike, which can also be replicated in any green space (either ones that are similar or different to those in our study). A range of values were applied to each indicator, which were established according to some existing scales and reference literature [32,34,47]. Each of these parameters and the range of values to be applied are detailed below. For better functionality, the indicators were grouped into three categories: Biodiversity, Accessibility/Facilities, and Infrastructure.

\subsubsection{Biodiversity Indicators}

This category reviews the indicators related to the species' biodiversity of green areas. This includes an indicator that measures the abundance of species and an indicator that refers to the negative effects that these species may have, such as allergenicity, toxicity, invasiveness, or emission of BVOCs. A summary of the indicators that make up this block is presented in the following table (Table 1):

Table 1. Values to assign to the indicators of the biodiversity category.

\begin{tabular}{|c|c|c|c|c|c|c|c|}
\hline$\%$ & $\begin{array}{c}\text { Species } \\
\text { Richness }^{1} \\
\end{array}$ & $\begin{array}{l}\text { Shannon' } \\
\text { Index }^{2}\end{array}$ & $\begin{array}{c}\text { Allergenic } \\
\text { Species }^{3}\end{array}$ & $\begin{array}{l}\text { Toxic/Poisonous } \\
\text { Species }\end{array}$ & $\begin{array}{l}\text { Invasive } \\
\text { Species }^{5}\end{array}$ & $\begin{array}{c}\text { Non- Native } \\
\text { Species }^{6} \\
\end{array}$ & $\begin{array}{c}\text { BVOCs } \\
\text { Emission }^{7} \\
\end{array}$ \\
\hline Low & $<2$ & $<2$ & $<20$ & $<10$ & $<1$ & $<10$ & $<20$ \\
\hline Moderate & $2-10$ & $2-3$ & $20-30$ & $10-15$ & $1-2$ & $10-50$ & $20-30$ \\
\hline High & $>10$ & $>3$ & $>30$ & $>15$ & $>2$ & $>50$ & $>30$ \\
\hline
\end{tabular}

1: Species richness: This represents the number of different species that exist in each UFT, considering each space as an ecological community. It does not consider the abundance of the species. When considering UFs of different types, among which there may be promenades or boulevards, often monospecific, we assigned a value of $<2$ for the lower range and a value of $>10$ to express a high richness [48].

2: Shannon Index: The Shannon Diversity Index is a quantitative measure that allows for the species' biodiversity (the relative abundance of each species) in a community to be estimated. In natural ecosystems, its value varies between 0.5 and 5 , although an acceptable value is between 2 and 3; values that are less than 2 are considered low in diversity and values that are greater than 3 are high in species diversity [49]. We applied this rank to the UFTs considered since they are components of an Urban Ecosystem. 
3: Allergenic species: To set the ranges for this category, those species that have a moderate or high Allergenic Potential Value (APV) according to the allergenicity scale proposed by Cariñanos et al., 2014, 2017, and Cariñanos and Marinangeli, 2021 [50-52] were considered. A percentage higher than $20 \%$ of allergenic species in a given UF is enough to be considered an allergenic risk for the sensitive population.

4: Toxic/Poisonous species: UFs are spaces visited by all kinds of social groups, some of them very vulnerable, such as children. The fact that $10 \%$ of plant species in UFs have toxic substances may already represent a moderate risk to this population. When $15 \%$ of species in UFs have toxic substances, it is considered to be a maximum risk [53,54].

5: Invasive species: The incorporation of exotic species as ornamentals in UFs has become one of the main entry ways for species that, after escaping from urban areas, have settled in the surrounding areas and thereby behave as invasive species [55]. For this indicator, we considered that a single species has sufficient potential to be considered a moderate risk [56].

6: Non-native species: Non-native species are considered those that have been introduced by humans [57]. Due to the long history that the incorporation of non-native species has had in Mediterranean urban forests [58], and the constancy of the invasive behavior that some of these species have developed [55], we considered that the categories established for this variable should be considered a potential disservice. When less than $10 \%$ of the total species in a given UF is non-native, the value is low. When the number is above $10 \%$, the value is considered to be moderate.

7: BVOCs' emissions: BVOCs' emissions have been classified according to the percentage of existing species with low $(<1)$, moderate $(<10)$, or high emissions $(>10)$ of BVOCS in micrograms VOC g Dry Weight $-1 \mathrm{~h}^{-1}$, according to existing reference scales $[59,60]$. The values assigned to the different categories of this service are similar to those of allergenic species: $<20 \%$ for low values and $>30 \%$ for high values.

\subsubsection{Accessibility/Facilities Indicators}

In this category, factors that can positively affect both user comfort and satisfaction are considered, so the indicator only expresses the presence (YES) or absence (NO) of these factors. Doing this highlights the existence of an aspect in need of improvement. If a specific indicator is marked as absent, this would have a negative effect for a particular population group such as the disabled, the elderly, children, or women (for example, accessibility or the existence of sports equipment or playgrounds), or on all population sectors (for example, the absence of any type of water element that provides a practical, aesthetic, or recreational functionality). The indicators that were considered for this section are listed below (Table 2):

Table 2. Proposed indicators for checking the Accessibility/Facilities category.

\begin{tabular}{ccc}
\hline & YES & NO \\
\hline Accessibility $^{8}$ & & \\
Water points $^{9}$ & & \\
Playgrounds $^{10}$ & & \\
Night lighting $^{11}$ & & \\
Outdoor fitness equipment $^{12}$ & \\
Sport facilities & \\
Rest area s $^{13}$ & & \\
Cleaning $^{15}$ & & \\
\hline
\end{tabular}

8: Accessibility: Universal access to UFs has been considered a right for all citizens. This indicator considers the existence of physical barriers that hinder access to vulnerable social groups: the disabled, the elderly, or people with reduced mobility in general [61].

9: Water points: Water points in UFs can have different functionalities, although in this category the practical (drinking fountains), aesthetic, or recreational services that they 
can offer to visitors were considered. Therefore, a total absence of water points should be subject to improvement in the short term. [62].

10: Playgrounds: Due to the proven health benefits that the presence of playgrounds in UFs have for children [63], the results of this indicator will allow for the planning of playground implementation in the most appropriate spaces according to the characteristics of the UF itself and the socio-economic environment in which it is located.

11: Night lighting: The scarcity or absence of night lighting has been labelled as a very negative factor due to the fear of crime and the insecurity it produces in UFs [64]. Its absence is notorious in those UFs that can be accessed at night.

12: Outdoor fitness equipment: The existence of outdoor fitness equipment encourages the performance of physical activity for the aged population. Thus, the absence of fitness equipment can negatively affect this population sector [65].

13: Sport facilities: The availability of sport facilities in UFs is one of the recreational services most appreciated by visitors due to the positive impact that sports can have on physical and mental health. As a result, the absence of sports facilities, even for things such as walking or running, can be a negative factor when visiting an UF [66].

14: Rest areas: One of the activities most valued by UF visitors is the contemplation of nature, relaxation, rest, and reflection. It is therefore necessary that rest areas, in the form of benches or other types of equipment, be available. [36]. Together with the accessibility indicator, the availability of rest areas is one of the most important factors to be addressed in case that they are absent.

15: Maintenance/Cleaning: The new maintenance strategies of UFs indicate that cleaning/dirt avoidance actions are one of the most successful improvement measures towards sustainable maintenance [67] and user satisfaction [66].

\subsubsection{Gray-Green-Blue Infrastructures' Indicators}

In this category, indicators were established for all aforementioned characteristics of UFs that, either due to the structural arrangement of their components or their superficial extension, can impede a correct provision of ecosystem services. They contemplate the three spheres of infrastructures that may be present in UF: blue, green, and gray. For the quantification of each indicator, i-Tree software was used. The i-Tree is a tool developed by the USDA Forest Service, and it is made up of different utilities that allow for the evaluation and quantification of the benefits and values that certain trees produce in urban environments [68]. The i-Tree Canopy tool is designed to estimate the percentage of vegetation cover and other cover classes within each study area. This tool places random points on Google Earth satellite images and determines the coverage class that the random point falls into. For our purposes, the following coverage categories were established: Tree/shrub cover and Grass/herbaceous surface (green infrastructure); Buildings and other gray infrastructure, Impervious soil (gray infrastructure); and Water elements in the form of small lakes, ponds, or ditches (which is different from the water points of the previous category) (blue infrastructure). The ranges to be applied to each indicator are presented in Table 3.

Table 3. Indicators proposed for checking the infrastructure category.

\begin{tabular}{cccccc}
\hline$\%$ & $\begin{array}{c}\text { Canopy/Shadow } \\
\text { Provision }^{\mathbf{1 6}}\end{array}$ & Impervious Soil ${ }^{\mathbf{1 7}}$ & Blue ELEMENTS ${ }^{18}$ & Grass Surface ${ }^{\mathbf{1 9}}$ & $\begin{array}{c}\text { Gray } \\
\text { Infrastructure }{ }^{\mathbf{2 0}}\end{array}$ \\
\hline Low & $>60$ & $<20$ & $>10$ & $<5$ & $<10$ \\
Moderate & $40-60$ & $20-40$ & $1-10$ & $5-10$ & $10-15$ \\
High & $<40$ & $>40$ & $<1$ & $>10$ & $>15$ \\
\hline
\end{tabular}

16: Canopy/Shadow provision: To establish the range of values of this parameter, the percentage of continuous surface and the spatial configuration of the trees were considered. Due to the high temperatures that can be registered during the summer in Mediterranean 
cities, a value of $40 \%$ of surface covered with trees was established as a minimum value for the effect of UFs on thermal comfort to be effective $[69,70]$.

17: Impervious soil: The high surface area of impervious soil in cities has been a cause of flooding and a decrease in water quality. The scale of values for this indicator was established on the basis that a waterproof coverage of $10 \%$ may increase up to $20 \%$ due to surface runoff [71].

18: Blue elements: The existence of blue infrastructure in UFs has an effect on mitigating the urban heat island effect, but also on mitigating pollution by both biological and non-biological particulate matter. Its total absence or low surface coverage can, therefore, be a relevant disservice [72,73].

19: Grass surface: The area covered with grass in areas with Mediterranean climate requires a large amount of water for maintenance, in addition to making it difficult for other species to form natural grasslands. A narrow range of values were established for the quantification of the service: an area greater than $10 \%$ of the total is sufficient for the applicable value to be the maximum [74].

20: Gray infrastructure: In a general way, gray infrastructure is comprised of constructed assets that occupy land. Then, the larger the area covered by gray infrastructure in a park, the less effect it will have on the provision of ecosystem services [75].

\section{Results}

In this work, indicators were used to check the characteristics that may affect the provision of ecosystem services and user comfort in 24 UFTs in the city of Granada. Of the 24 selected UFs, 11 of them have a surface area of less than $10,000 \mathrm{~m}^{2}$, which mainly includes typologies such as squares, tree alignments, boulevards, and pocket parks, and which are among the best represented in the city of Granada. The remaining UFs have an area that ranges between 13,500 (Quinta Alegre Garden) and 71,500 m² (García Lorca Park). This category includes some gardens, city parks, and the Bosque de Gomerez, one of the urban forests that surrounds the monument of La Alhambra. Regarding their management, 20 are managed by the Park and Garden Service of the Granada City Council, two are managed by the University of Granada (the Arboretum and the Botanical Garden of the Faculty of Law), and two are managed by the Board of the Alhambra (the Forest of Gomerez and the Carmen de los Martires). Other characteristics of UFs including species richness, number of trees, and percentage of allergenic trees are presented in Supplementary Material Table S1. The results obtained after applying the three categories of established indicators, Biodiversity, Accessibility / Facilities, and Infrastructure, are presented below.

\subsection{Biodiversity Indicators}

The application of the values assigned to each of the indicators of the Biodiversity category (Table 4) reveals that for indicator 1 , most of the UFTs have an adequate species richness, with more than 10 different species in each, regardless of their typology. However, this is not transferable to the Shannon Diversity Index (indicator 2) since some parks have a value lower than 3 , which can be considered as low diversity. In relation to the percentage of allergen-emitting species (indicator 3), it is notable that almost all types are above $30 \%$, although this cannot be interpreted as a high Allergenicity Index value for the UFTs as a whole. Regarding the percentage of toxic species (indicator 4), the presence in some spaces of several species with some toxic part, such as seeds (Malus spp., Prunus spp.), bark, leaves, flowers, fruits (Melia azedarach, Ligustrum lucidum, Robinia pseudoacacia, Aesculus hippocastanum), or the whole plant (Schinus molle, Taxus baccata) is noteworthy. The indicator on the number of invasive species (indicator 5) considers the presence of only two species as a high value. Although most UFTs do not contain any, or only one, the total list of species of all the parks includes some of those with the greatest invasive potential: Acacia dealbata, Ailanthus altissima, Eleagnus angustifolia, Eucalyptus camaldulensis, Gleditsia triacanthos, and Robinia pseudoacacia. Closely related to this indicator is the percentage of non-native species (indicator 6), which is higher than $50 \%$ of all the species present in most of the green areas 
considered. The percentage of species emitting BVOCs (indicator 7) is also very high, which exceeds $30 \%$ of all species, with the most frequent being Platanus $\mathrm{x}$ hispanica, and several species of the Populus and Quercus genera, all of them highly represented in the different types of UFs. Similar to the allergenicity indicator, moderate- to high-emission species were considered.

Table 4. Results obtained for the Biodiversity indicators of the different UFs.

\begin{tabular}{|c|c|c|c|c|c|c|c|c|c|c|c|c|c|c|c|c|c|c|c|c|c|c|c|c|}
\hline IND & $\mathrm{AE}$ & AP & BG & BGU & BO & $\mathrm{CC}$ & CL & $\mathrm{CM}$ & $\mathrm{CV}$ & FN & FS & GA & GL & PC & PCO & PM & PS & PT & $\mathbf{P V}$ & QA & SF & TG & TM & TMO \\
\hline 1 & & & & & & & & & & & & & & & & & & & & & & & & \\
\hline 2 & & & & & & & & & & & & & & & & & & & & & & & & \\
\hline 3 & & & & & & & & & & & & & & & & & & & & & & & & \\
\hline 4 & & & & & & & & & & & & & & & & & & & & & & & & \\
\hline 5 & & & & & & & & & & & & & & & & & & & & & & & & \\
\hline 6 & & & & & & & & & & & & & & & & & & & & & & & & \\
\hline 7 & & & & & & & & & & & & & & & & & & & & & & & & \\
\hline
\end{tabular}

AE: Albert Einstein Plaza; AP: Almunia Park; BG: Gomerez Forest; BGU: University Botanical Garden; BO: Bola de Oro Park; CC: Carlos Cano Park; CL: Cruz de Lagos Park; CM: Carmen de los Martires Garden; CV: Carrera de la Virgen Park; FN: Fuentenueva Park; FS: Faculty of Sciences Arboretum; GA: Garcia Arrabal Park; GL: Garcia Lorca Park; PC: Concordia Plaza; PCO: Palace of Congresses Park; PM: Mariana Pineda Park; PS: Paseo del Salon Blvd.; PT: Trinidad Plaza; PV: Paseo del Violon Blvd.; QA: Quinta Alegre Garden; SF: San Fernando Plaza; TG: Triunfo Gardens; TC: Tico Medina Park; TMO: Tete Montoliu Park. Low $\square$ Moderate $\square$ High

\subsection{Accessibility/Facilities Indicators}

The factors checked in this category (Table 5) revealed that all UFTs have rest areas in the form of benches and rest places (indicator 14). Most UFTs (19 out of 24) are also accessible to population groups with reduced mobility, in which there are no obstacles to access or to have a walk inside (indicator 8). However, the absence of ramps and the presence of stairs in several UFs has a limiting effect. Poor cleaning (indicator 15) and the absence of night lightning (indicator 11) are important limitations in eight UFs, while the absence of water elements (indicator 9), which includes drinking fountains, is shared by 10 spaces. The major deficiencies in the UFTs are the absence of playgrounds (indicator 10) or outdoor fitness facilities (indicator 12), which are absent in 16 and 18 UFs, respectively. These deficiencies may cause displeasure to both children and the elderly.

Table 5. Results obtained for the Accessibility/Facilities indicators of the different UFs.

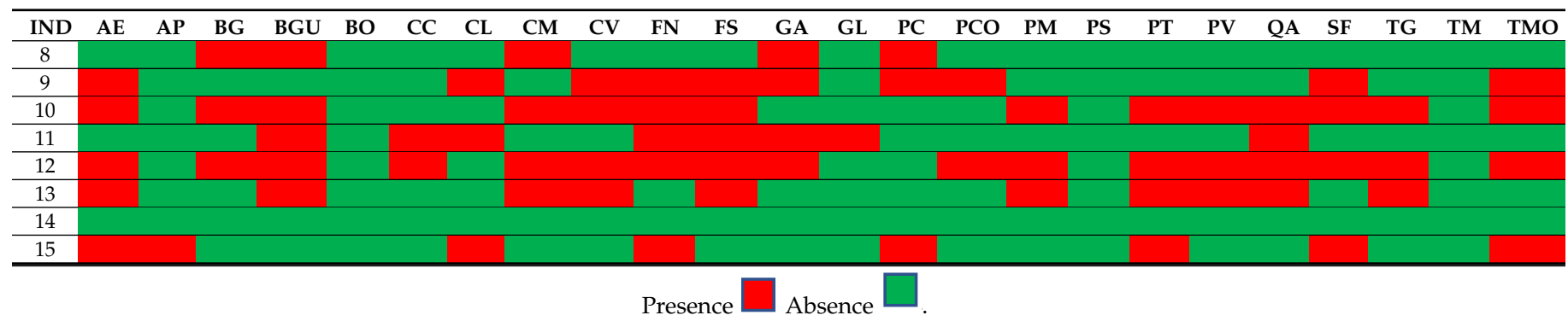

\subsection{Infrastructure Indicators}

After applying the indicators related to infrastructure (Table 6), it was observed that water elements (indicator 18) are absent in 18 of 24 parks. The percentage of tree cover, that is, the continuous area covered by tree canopy (indicator 16), registers values of $<40 \%$ in a high number of spaces. However, spaces such as the Gomerez Forest, University Botanical Garden, Carmen de los Martires Garden, Carrera de la Virgen Park, Mariana Pineda Park, and Trinidad Plaza have a canopy percentage of $>60 \%$ of their total area. The percentage of impervious cover (indicator 17) is higher than $20 \%$ in 14 of out 24 UFs, but it reaches more than $40 \%$ in areas such as Albert Einstein Plaza. Although the majority of UFs have a grass coverage of less than 5\% (indicator 19), in some, such as Gomerez Forest, Bola de Oro Park, Fuentenueva Park, Garcia Arrabal Park, Garcia Lorca Park, Triunfo Gardens, and Tico Medina Park, there are lawn areas greater than $10 \%$ of the total area. The existence of 
gray infrastructure elements is quite low, and it is only relevant in the University Botanical Garden, due to its location attached to the Faculty of Law and is moderate in the park surrounding the Palace of Congresses Park, where this building represents most of the gray infrastructure present.

Table 6. Results obtained for the Infrastructure indicators of the different UFs.

\begin{tabular}{|c|c|c|c|c|c|c|c|c|c|c|c|c|c|c|c|c|c|c|c|c|c|c|c|c|}
\hline IND & $\mathrm{AE}$ & AP & BG & BGU & BO & CC & $\mathrm{CL}$ & $\mathrm{CM}$ & CV & FN & FS & GA & GL & PC & PCO & PM & PS & PT & PV & QA & SF & TG & TM & TMO \\
\hline 16 & & & & & & & & & & & & & & & & & & & & & & & & \\
\hline 17 & & & & & & & & & & & & & & & & & & & & & & & & \\
\hline 18 & & & & & & & & & & & & & & & & & & & & & & & & \\
\hline 19 & & & & & & & & & & & & & & & & & & & & & & & & \\
\hline 20 & & & & & & & & & & & & & & & & & & & & & & & & \\
\hline
\end{tabular}

\section{Discussion}

In this work, we proposed indicators that allow for a preliminary check on the state of some of the functions and services provided by the UFTs of a medium-sized Mediterranean city. For this, a series of measurable values were assigned to 20 parameters of different categories, so that they can be applied in a simple way and be easily interpreted by experts and non-experts [76]. This proposal is inspired by other existing ones in which both ecosystem services and disservices were quantified through models, direct measurements, or from the reviewed scientific literature $[29,33,77]$. In this case, we adjusted the indicators to the particularities and idiosyncrasies of Mediterranean cities, characterized by their compactness, population density, and vulnerability to the effects of climate change [78]. The list of indicators of the existing services in UFTs aims to be an easy-to-use tool that highlights the improvement actions necessary to reinforce the role of green areas in the framework of a sustainable and resilient city [79].

For the assessment of disservices, 24 urban forests of different types were selected, which are the most characteristic of the Mediterranean region in which historical urban development has generated compact model cities with high population densities and little green area [15]. In this framework, spaces with a surface area greater than $10,000 \mathrm{~m}^{2}$ are particularly relevant, represented in our list by City Parks, which have been identified as one of the urban forest types with the greatest significance to address some of the most important challenges at local and global level $[1,80]$. However, if there is one type of urban forest that should stand out for its eminent Mediterranean character, it is the small plaza types and squares (also called pocket parks). These spaces have a surface area of less than 1 hectare, are accessible, safe, and attractive, and allow people to carry out a large number of socialization and recreation activities $[20,81]$. Their abundance in numerous cities (for example, more than $90 \%$ of existing public green areas in Granada [38]), and their location in historic city centers $[81,82]$ mean that a special focus should be made to review and fine-tune all those aspects that are affecting the provision of ecosystem services. The important demographic challenges that the Mediterranean region must face in the coming decades, with intra- and inter-country migratory flows and the region's vulnerability to climate change [83], should accelerate the planning of operational measures that make UFTs healthier, more visible, inclusive, cohesive, aesthetic, equitable, enjoyable, and, ultimately, sustainable places.

The 20 indicators were grouped into three categories to plan improvement joint interventions. In the category of Biodiversity indicators, it is evident that the emitting capacity of allergens and BVOCs of different plant species was not considered when selecting the species that form urban forests. Both services need urgent mitigation measures given their impact on health and the environment [84,85]. Some authors point out the diversification of the flora, the selection of individuals/strains with low pollen production, proper management, and knowledge of the functional traits of the species as solutions for reducing the impact of emissions of allergens and BVOCs [34,84-86]. The percentage of 
toxic and/or poisonous species in UFs does not represent a serious problem, since the most vulnerable groups have been adequately warned [87].

Several species used in UGI have invasive behavior and their use should be discontinued. They should be identified and controlled in nurseries to avoid their incorporation into UGI elements, and a specific and proactive handling of the specimens that are already installed in UFs are some of the actions to be carried out to avoid the spread and incorporation of new invasives. [24]. Priority attention should be paid to species such as Ailanthus altissima, already mentioned as one of the most invasive species in the Mediterranean region, and whose colonization in vulnerable ecosystems is considered an important threat to native species [88].

The Accessibility/Facilities block includes indicators that can improve the well-being and satisfaction of UFT users, although there are important differences between the spaces considered in this study. Thus, while in most of these spaces there are rest areas, mainly seats, and they are accessible to people with motor disabilities, playgrounds and fitness facilities are absent in a good number of them. These Park facilities have been shown to have a multifunctional role as elements for socialization and health within the framework of sustainable cities [89], so their incorporation into the design should be considered a priority in all those UFTs that have a primary social function, which would include those of the City Parks, Boulevards, and pocket parks located both close to historic districts and in new neighborhoods to serve a wide range of social groups. The installation of water elements is also urgent, specifically in the form of drinking fountains due to the impact that climate change may have in the Mediterranean region, where a significant increase in temperature and greater frequency and intensity of heat waves are expected [90]. The amount and area of the blue points (water) identified in most of the green spaces are not significant in ecological terms, since these points are not usually large enough to influence the local temperature of the studied areas. These water points have aesthetic purposes or come in the form of drinking fountains and, therefore, it is not considered that they could ameliorate urban heat island events. It is also important to review the current water services so that they can be used safely in situations such as those generated by the COVID-19 pandemic [91].

Two indicators that are included in this block deserve particular attention: poor cleaning and the absence of night lightning. Cleaning or proper management of public spaces is one of the most valued services when surveys of the user population are carried out $[92,93]$. Therefore, the presence of dirt derived from poor cleaning is a clear negative factor. In our study, it was observed that those UFTs furthest away from the Historic Center are those with the most garbage and plastic bottles on the ground. Full bins, graffiti, and animal feces are also common in these areas. The improvement of this service implies a greater investment of human and economic resources on the part of the Municipal Parks and Gardens Maintenance Services, which, in most cases, it does not have the capacity or flexibility to modify the traditional handling and maintenance actions that have been carried out for a long time [94]. However, perhaps now is the time to plan new management perspectives in which not only aesthetic and cultural services predominate but also align as closely as possible to the natural dynamics of these urban ecosystem components [95].

Security, specifically the lack of security in parks that are poorly lit at night, is one of the issues most frequently pointed out by the surveyed population. Walking or crossing isolated parks, at night and with poor lighting, are some of the main attributes that evoke fear of crime in public urban parks. Individual factors such as gender and past experiences compound this problem [96,97]. In our study, adequate night lighting is absent in some of the UFTs that usually close access for night visitors, such as the Faculty of Sciences, the University Botanical Garden, or the Quinta Alegre Garden, but also others that are in very populated districts such as the Cruz de Lagos Park, the Carlos Cano Park, or the Fuentenueva Park, in which these lighting characteristics should be reviewed.

The infrastructure indicators contemplate the presence and extension of the elements corresponding to the green, blue, and gray spheres. One of the most outstanding disservices 
is that of the blue elements in the form of small lakes, ponds, or monumental fountains. Although the presence of water elements has been a historical tradition closely linked to Mediterranean gardens, brought to their maximum splendor with the Italian Renaissance water gardens [98], their presence in current UFs has been greatly reduced. One of the reasons for this reduction is the importance of the water economy in the management of green areas, which is being imposed throughout the region as a result of the growing water deficit. This requires the implementation of new strategies for efficient water management, both to irrigate the spaces and to retain rainwater [99].

Closely related to this indicator are indicators 17 and 19, related to the percentage of impervious soil and surface area covered with grass. The amount of impermeable soil in UFTs is the origin of several important disservices such as the increase in runoff during periods of intense rainfall [71] or the exacerbation of the urban heat island effect [100]. Given the climate scenario forecasts for the Mediterranean region, with estimated temperature increases of up to $2{ }^{\circ} \mathrm{C}$ and a reduction of $30 \%$ in average annual precipitation [101], a transformation of these impervious surfaces into permeable soil is not only necessary but also urgent. On occasions, substituting compacted pavements with permeable pavements could lead to economic savings, with a significant return on investment when balancing costs due to flooding and replacement costs [102].

Regarding grass-covered areas, the progressive substitution of grass lawns by covers of native species with less water requirements is a debate already open in cities with Mediterranean climate $[74,103]$. Among the main Nature-based Solutions for the sustainable management of urban parks, the naturalization of the current lawns and grasslands is being contemplated, allowing for the introduction of native species that are better adapted to the prevailing climatic and ecological conditions [74,104]. The provision of ecosystem services, such as the conservation and improvement of biodiversity, the attraction of pollinators, the improvement of soil microorganisms, and the reinforcement of the population dynamics of the vegetation, would significantly mitigate the impact of the current disservice.

Finally, the results obtained for indicator 16, which establishes the percentage of continuous surface covered by tree canopy, were analyzed. This indicator can have different interpretations, since it is a value that is used for the assessment of ecosystem services, such as the mitigation of air pollution [105] or the reduction of the kinetic impact of raindrops [106]. In our case, since the purpose was to carry out a check on the current state of UFs and its immediate effect on the comfort of users, we associated the canopy percentage to the provision of shade, since one of the characteristics that can most prevent visits to UFs is the lack of thermal comfort. Our results have revealed that more than half of the UFs in Granada have a tree canopy of less than $40 \%$, which is why they would also have a deficit in terms of the provision of shade. In the Mediterranean region, where the number of hours of sunshine/year is higher than 2500 [107] and UV radiation is one of the highest on the planet [108], the shaded spaces under tree canopies become authentic oases of shelter for a good number of hours a day [109]. These shaded spaces have also been shown to have a restorative effect on the mental health of the population, and to be cohesive and socializing elements in neighborhoods [110]. An improvement measure would entail the transformation of the extensive area of impervious soil that many of the parks have into a useful area for tree planting. This action would, in turn, take part in the greening process that many cities are undertaking as an urban resilience reinforcement measure, to address the impacts of climate change more adequately.

\section{Conclusions}

In this work, a series of indicators are proposed that allow for the status of some functions and services provided by urban forests of different typology to be checked. This work is extremely important since it allows for the evaluation of different future alternatives for better adaptation to climatic scenarios, urban growth, and population needs, which stakeholders can use in their decisions. Knowing the status of UFTs is an indicator of 
sustainable cities, where the management of public areas and ecosystem services, together with good environmental policies and development plans, are essential in areas affected by climate change, as is the case of Mediterranean cities.

Compact cities, such as Mediterranean urban areas with high population densities and a scarcity of green spaces, may have better urbanization plans in which, if the increase in urban green areas is not possible, there is the possibility of improving the quality of the green areas that already exist. Addressing the deficiencies of these areas based on the 20 proposed indicators may result in an improvement in aspects like the thermal comfort for the population or a reduction in cases of allergenicity.

It is also important to note that the selection of native arboreal species is important for maintenance costs. In those green spaces with a typology of city and pocket parks whose purpose is to provide recreation, it is important to visualize the aspects of improving accessibility and infrastructure facilities so that they can be used by all segments of the population. Likewise, it is not only the lack of blue infrastructure but considering their size and location within green areas would improve temperature and humidity.

The high percentage of impermeable soil is an aspect to be highlighted, since although it is necessary in some areas for accessibility, impervious areas were also found without any purpose, which could be replaced with vegetation, which allows for the filtration of rainwater. This is related to the fact that more than half of the UFTs studied have a percentage of less than $40 \%$ tree canopy. This lack of tree canopy is directly related to problems in mitigating urban heat islands and capturing polluted air.

Adopting strategies that are focused on future climate scenarios in Mediterranean cities is a key element in adapting public spaces to mitigate their own negative impacts on human health and ecosystem services. Therefore, the proposed set of indicators allows for a general assessment of the readiness of UFTs in Mediterranean cities to face the important climatic, social, and ecological challenges in the near future.

Supplementary Materials: The following are available online at https: / www.mdpi.com/article / 10.3390/f12101320/s1. Table S1: Characteristics of the 24 urban forests considered in this study.

Author Contributions: M.F.M.-M. and P.C. are both responsible for the conceptualization, methodology, formal analysis, investigation, resources, data curation, writing-original draft preparation, and writing-review and editing. All authors have read and agreed to the published version of the manuscript.

Funding: This research received no external funding.

Institutional Review Board Statement: Not Applicable.

Informed Consent Statement: Not Applicable.

Data Availability Statement: Characteristics of the 24 urban forests considered in this study.

Conflicts of Interest: The authors declare no conflict of interest.

\section{References}

1. Salbitano, F.; Borelli, S.; Conigliaro, M.; Chen, Y. Guidelines on Urban and Periurban Forestry; FAO Forestry Papers N; Food and Agriculture Organization of the United Nations: Rome, Italy, 2016.

2. Benedict, M. How Cities Use Parks for Green Infrastructure; City Parks Forum Briefing Papers; American Planning Association: Chicago, IL, USA, 2004.

3. Mexia, T.; Vieira, J.; Príncipe, A.; Anjos, A.; Silva, P.; Lopes, N.; Freitas, C.; Santos-Reis, M.; Correia, O.; Branquinho, C.; et al. Ecosystem Services: Urban parks under a magnifying glass. Environ. Res. 2018, 160, 469-478. [CrossRef]

4. Palliwoda, J.; Banzhaf, E.; Priers, J.A. How do the green components of urban green infrastructure influence the use of ecosystem services? Examples from Leipzig, Germany. Landsc. Ecol. 2020, 35, 1127-1142. [CrossRef]

5. Mao, Q.; Wang, L.; Guo, Q.; Li, Y.; Lin, M.; Xu, G. Evaluating Cultural Ecosystem Services of Urban Residential Green Spaces from the perspectives of Residents' Satisfaction with green spaces. Front. Public Health 2020, 8, 226. [CrossRef]

6. Torabi, N.; Lindsay, J.; Smith, J.; Khor, L.A.; Sainsbury, O. Widening the lens: Understanding urban parks as a network. Cities 2020, 98, 102527. [CrossRef] 
7. Jennings, V.; Bamkole, O. The relationship between social cohesion and urban green space: An Avenue for Health promotion. Int. J. Environ. Res. Public Health 2019, 16, 452. [CrossRef]

8. Cariñanos, P.; Calaza, P.; Hiemstra, J.; Peralmutter, D.; Vilhar, U. The role of urban and peri-urban forests in reducing risks and mananging disasters. Unasylva 2018, 69, 53-58.

9. Ugolini, F.; Masseti, L.; Calaza-Martínez, P.; Cariñanos, P.; Dobbs, C.; Krajter-Ostoic, S.; Marin, A.M.; Pearlmutter, D.; Saaroni, H.; Sauliene, I.; et al. Effects of the COVId-19 pandemic on the use and perceptions of urban Green space: An international exploratory study. Urban For. Urban Green. 2020, 56, 126888. [CrossRef] [PubMed]

10. Corkery, L.; Marshall, N. Urban Parks and open space: Underpinning a city's future resilience. Analysis and Policy Observatory. In Proceedings of the 8th State of Australian Cities National Conference, Adelaide, Australia, 28-30 November 2018.

11. Canals Ventín, P.; Lázaro Marín, L. Towards Nature-Based Solutions in the Mediterranean; IUCN Centre for Mediterranean Cooperation: Málaga, Spain, 2019.

12. Woertz, E. Notes Internacionals CIDOB: Mediterranean Cities, the Urban Dimension of the European Neighborhood Policy. In Mediterranean Cities, the Urban Dimension of the European Neighborhood Policy (6); CIDOB: Barcelona, Spain, 2018.

13. Chaline, C. Urbanisation and Town Management in the Mediterranean Countries. Assessment and Perspectives for Sustainable Urban Development; Mediterranean Commission on Sustainable Development:UNEP-MAP/BP-RAC: Sophia Antipolis, France, 2001.

14. Blue Plan. Cities and Sustainable Development in the Mediterranean; Mediterranean Comission on Sustainable Development: Sophia Antipolis, France, 2000.

15. Salvati, L.; Morelli, V.G. Unveiling urban sprawl in the Mediterranean Region: Towards a latent Urban Transformation. Int. J. Urban Reg. Res. 2014, 38, 1935-1953. [CrossRef]

16. Fullerm, R.A.; Gaston, K.J. The scaling of green space coverage in European cities. Biol. Lett. 2009, 5, 352-355. [CrossRef] [PubMed]

17. Haaland, C.; van den Bosh, C.K. Challenges and strategies for urban green-spaces planning in cities undergoing densification: A Review. Urban For. Urban Green. 2015, 14, 760-771. [CrossRef]

18. Kabish, N.; Haase, D. Green spaces of European cities revisited for 1990-2006. Landsc. Urban Plan. 2013, 110, 113-122. [CrossRef]

19. Gospodini, A.; Brebbia, C.A.; Tiezzi, E. (Eds.) The Sustainable City V: Urban Regeneration and Sustainability; Wit Press: Southampton, UK, 2008; Volume 5.

20. Adinolfi, C.; Suárez-Cáceres, G.P.; Cariñanos, P. Relation between visitors'behaviour and characteristics of green spaces in the city of Granada, south-eastern Spain. Urban For. Urban Green. 2014, 13, 534-542. [CrossRef]

21. European Route of Historic Gardens. Cultural Routes of the Council of Europe. Available online: http:/ /ww.europeanhistoricgardens.eu (accessed on 18 August 2021).

22. Tomlison, I.; Potter, C.; Bayliss, H. Managing tree pests and diseases in urban settings: The case of oak Processionary moth in London, 2006-2012. Urban For. Urban Green. 2015, 14, 286-292. [CrossRef]

23. Gaertner, M.; Wilson, J.R.U.; Cadotte, M.W.; MacIvor, J.S.; Zenni, R.D.; Richardson, D.M. Non-native species in urban environments: Pattern, processes, impacts and challenges. Biol. Invasions 2017, 19, 3461-3469. [CrossRef]

24. Calfapietra, C.; Fares, S.; Manes, F.; Morani, A.; Sgrigna, G.; Loreto, F. Role of Biogenic Volatile Organic Compounds (BVOC) emitted by urban trees on ozone concentration in cities: A review. Environ. Pollut. 2013, 183, 71-80. [CrossRef] [PubMed]

25. Cariñanos, P.; Adinolfi, C.; de la Guardia, C.D.; de Linares, C.; Casares-Porcel, M. Characterization of allergen emission sources in urban areas. J. Environ. Qual. 2016, 45, 244-252. [CrossRef] [PubMed]

26. Aram, F.; Solgi, E.; Baghaee, S.; Higueras-García, E.; Mosavi, A.; Band, S.S. How parks provide thermal comfort perceptions in the metropolitan cores; a case-study in Madrid, Mediterranean climate zone. Clim. Risk Manag. 2020, 30, 100245. [CrossRef]

27. Heywood, V.H. The nature and composition of urban plants diversity in the Mediterranean. Flora Mediterr. 2017, $27,195-220$.

28. Liu, R.; Xiao, J. Factors affecting users' satisfaction with urban parks through online comments data: Evidence from Shenzen, China. Int. J. Environ. Res. Public Health 2021, 18, 252.

29. De Groot, R.; Wilson, M.A.; Boumans, R.M. A Typology for the classification, description and valuation of ecosystems functions. goods and services. Ecol. Econ. 2002, 41, 393-408. [CrossRef]

30. Dobbs, C.; Escobedo, F.J.; Zipperer, W.C. A framework for developing urban forests ecosystem services and good indicators. Landsc. Urban Plan. 2004, 99, 196-206. [CrossRef]

31. Davies, H.; Doick, K.; Handley, P.; O’Brien, L.; Wilson, L. Delivery of ecosystem services by urban forests. Res. Rep. For. Comm. UK 2017, 26, 77.

32. von Döhren, P.; Haase, D. Ecosystem disservices research: A review of the state of the art with a focus on cities. Ecol. Indic. 2015, 52, 490-497. [CrossRef]

33. von Döhren, P.; Haase, D. Risk assessment concerning urban ecosystem disservices: The example of street trees in Berlin, Germany. Ecosyst. Serv. 2019, 40, 101031. [CrossRef]

34. Lyytimäki, J. Disservices of urban trees. In Routledge Handbook of Urban Forestry; Ferrini, F., van den Bosch, C.K., Fini, A., Eds.; Routledge Taylor and Francis: London, UK; New York, NY, USA, 2017.

35. Cariñanos, P.; Calaza, P.; O’Brien, L.; Calfapietra, C. The cost of greening: Disservices of urban trees. In The Urban Forests: Cultivating Green Infrastructure for People and the Environment; Pearlmutter, D., Calfapietra, C., Samson, R., O'Brien, L., KrajterOstoic, S., Sanesi, G., Alonso, R., Eds.; Springer International Publishing AG: Cham, Switzerland, 2017. 
36. Vieira Martins, L.F.; Bittas Venturi, L.A.; Belem Wingter, G. A monitoring system proposal for urban parks in Valley bottoms. Ambiente Soc. 2019, 22, e00243. [CrossRef]

37. Blaszczyk, M.; Suchocka, M.; Wojnowska-Heciak, M.; Myszynska, M. Quality of urban parks in the perception of city residents with mobility difficulties. PeerJ 2020, 8, e10570. [CrossRef]

38. Delgado-Capel, M.; Cariñanos, P. Towards a Standard Framework to Identify Green Infrastructure Key Elements in Dense Mediterranean Cities. Forests 2020, 11, 1246. [CrossRef]

39. IUCN. Nature Based Solutions in Mediterranean Cities. Rapid Assessment Report and Compilation of Urban Nventories (2017-2018); IUCN: Málaga, Spain, 2019; p. 117.

40. UrbiStat. Maps, Analysis and Statistics about the Resident Population. Municipality of Granada. Available online: https://ugeo.urbistat.com/AdminStat/en/es/demografia/dati-sintesi/granada/20234622/4 (accessed on 12 September 2021).

41. National Institute of Statistics (INE). Población Residente por Fecha, Sexo y Edad. Resultados por Provincias. Available online: https: / / www.ine.es/jaxiT3/Tabla.htm?t=31304 (accessed on 31 July 2020).

42. Granada Instituto de Estadística y Cartografía de Andalucía; Consejeria de Transformación Económica, Industria, Conocimiento y Universidades; Junta de Andalucía. Sistema de Información Multiterriorial de Andalucia (SIMA); Granada Instituto de Estadística y Cartografía de Andalucía: Granada, Spain; Consejeria de Transformación Económica, Industria, Conocimiento y Universidades: Seville, Spain; Junta de Andalucía: La Roda de Andalucía, Spain, 2021.

43. State Agency of Meteorology (AEMET). Status Report of the Climate of Spain Executive Summary; Ministry for the Ecological Transinction and Demographic Challenge, Government of Spain: Madrid, Spain, 2020.

44. Cuadrat, J.; Serrano-Notivoli, R.; Tejedor, E. Heat and Cold Waves in Spain. In Fenómenos Meteorológicos Adversos en España; Ediciones García Legaz, A.M.V., Rodríguez, V., Eds.; World Climate Research Programme: Geneva, Switzerland, 2013.

45. Casquero-Vera, J.A.; Titos, G.; Alados-Arboledas, L. Diagnóstico de la Calidad del Aire del Área Metropolitana de Granada; Agenda Ayuntamiento de Granada; Instituto Interuniversitario de Investigación del Sistema Tierra en Andalucía, Universidad de Granada: Granada, Spain, 2016.

46. Cariñanos, P.; Foyo-Moreno, I.; Alados, I.; Guerrero-Rascado, J.L.; Ruiz-Peñuela, S.; Titos, G.; Cazorla, A.; Alados-Arboledas, L.; Díaz de la Guardia, C. Bioaerosols in urban environments: Trends and Interactions with pollutants and meteorological variables based on quasi-climatological series. J. Environ. Manag. 2021, 282, 111963. [CrossRef]

47. Wu, S.; Li, B.V.; Li, S. Classifying ecosystem disservices and valuating their effects-A case study of Beijing, China. Ecol. Indic. 2021, 129, 107977. [CrossRef]

48. Gotelli, N.J.; Colwell, R.K. Estimating Species Richness. In Biological Diversity: Frontiers in Measurement and Assessment; Oxford University Press: Oxford, UK, 2011; Volume 39, p. 54.

49. Shannon, C.E.; Weaver, W. The Mathematical Theory of Communication; University Illinois Press: Urbana, IL, USA, 1949.

50. Cariñanos, P.; Casares-Porcel, M.; Quesada-Rubio, J.M. Estimating the allergenic potential of urban green spaces: A case-study in Granada, Spain. Landsc. Urban Plan. 2014, 123, 134-144. [CrossRef]

51. Cariñanos, P.; Casares-Porcel, M.; Díaz de la Guardia, C.; Aira, M.J.; Belmonte, J.; Boi, M.; Elvira-Rendueles, B.; De Linares, C.; Fernández-Rodriguez, S.; Maya-Manzano, J.M.; et al. Assessing allergenicity in urban parks: A nature-based solution to reduce the impact on public health. Environ. Res. 2017, 155, 219-227. [CrossRef]

52. Cariñanos, P.; Marinangeli, F. An Updated proposal of the Potential Allergenicity of 150 ornamental trees and shrubs in Mediterranean Cities. Urban For. Urban Green. 2021, 63, 127218. [CrossRef]

53. Nelson, N.L.; Shih, R.P.; Ballick, M.J. Handbook of Poisonous and Injurious Plants; Springer: New York, NY, USA; The New York Botanical Garden: New York, NY, USA, 2007.

54. Wagstaff, J. International Poisonous Plants Checklist. An Evidence-Based Reference; CRC Press/Taylor and Francis Group: Boca Raton, FL, USA, 2007.

55. Bayón, A.; Vilá, M. Horizon scanning to identify invasion risk of ornamental plants marketed in Spain. NeoBiota 2019, 52, 47-68. [CrossRef]

56. Sanz Elorza, M.; Dana Sanchez, E.; Sobrino Vesperias, E. Plantas Alóctonas Invasoras de España; Ministerio de Medio Ambiente, Dirección General para la Biodiversidad, Gobierno de España: Madrid, Spain, 2004.

57. Hettinger, N. Exotic species, naturalisation, and biological nativism. Environ. Values 2011, 10, 193-224. [CrossRef]

58. Bodilis, P.; Francour, P.; Langar, H.; El Asmi, S. Non-Native Species in the Mediterranean: What, When, How and Why? UNEP-MAPRAC/SPA; RA/SPA: Tunis, Tunisia, 2011.

59. Singh, R.; Singh, M.P.; Sing, A.P. Ozone forming potential of tropical plant species of the Vidarbha region of Maharashtra state of India. Urban For. Urban Green. 2014, 13, 814-820. [CrossRef]

60. Karl, M.; Guenther, A.; Köble, R.; Leip, A.; Seufert, G. A new European plant-specific emission inventory of biogenic volatile organic compounds for use in atmospheric transport model. Biogeosciences 2009, 6, 1059-1087. [CrossRef]

61. Güngor, S.; Demir, M.; Polat, A.T. A Research on Accessibility of urban parks by disabled users. Int. J. Res. Soc. Sci. 2016, 6, 578-594.

62. Tarim, A. Position of water elements as an urban furniture. Int. J. Res. Clin. Metall. Civ. Eng. 2017, 4, 43-44.

63. Zuo, K.; Wei, L.; Cong, Y. Exploration of Natural Playgrounds in Urban Parks: Promoting Childrens's Health. Urban Reg. Plan. 2020, 5, 122-131. [CrossRef] 
64. Mahrour, A.M.; Moustafa, Y.M.; El-Ela, M.A.A. Physical characteristics and perceived security in urban parks: Investigation in the Egyptian context. Ain Shams Eng. J. 2018, 9, 3055-3066. [CrossRef]

65. Chow, H.W. Outdoor fitness equipment in parks: A qualitative study from older adults. BMC Public Health 2013, 13, 1216. [CrossRef]

66. Voigt, A.; Kabish, N.; Wurster, D.; Haase, D.; Breuste, J. Structural Diversity: A multi-dimensional approach to assess recreational services in urban parks. AMBIO 2014, 43, 480-491. [CrossRef]

67. Granz, G.; Boland, M. Defining the Sustainable Park: A Fith Model for Urban Parks. Landsc. J. 2004, 23, $102-120$.

68. i-Tree User's Manual. Tools for Assessing and Managing Community Forests. Software Suite v6. 2016. Available online: https:/ / www.itreetools.org/resources/manuals/i-Tree\%20Species\%20Users\%20Manual.pdf (accessed on 15 July 2021).

69. Moreno-García, M.C. The microclimate effect of Green Infrastructure (GI) in a Mediterranean city: The case of the urban park of Ciutadella (Barcelona, Spain). Agric. Urban For. 2019, 45, 100-108.

70. Zhou, W.; Wang, J.; Cadenasso, M.L. Effects of the Spatial configuration of trees on urban heat mitigation: A comparative study. Remote. Sens. Environ. 2017, 195, 1-12. [CrossRef]

71. Flinker, P. The Need to Reduce Impervious Cover to Prevent Flooding and Protect Water Quality; Department of Environmental Management: Providence, RI, USA, 2010.

72. Wu, D.; Wang, Y.; Fan, C.H.; Xia, B. Thermal environment affects and interactions of reservoir and forests as urban green infrastructures. Ecol. Indic. 2018, 91, 657-663. [CrossRef]

73. Zuvela-Aloize, M.; Koch, R.; Bucholz, S.; Früh, B. Modelling the potential of green and blue infrastructure to reduce urban heat load in the city of Vienna. Clim. Chang. 2016, 135, 425-438. [CrossRef]

74. Alonso-Martínez, P.; Castro, M.C.; Pinto-Gomes, C. Flowering meadows, a biodiverse alternative to lawns in Mediterranean urban spaces. In The Garden as a Lab. Where Cultural and Ecological Systems Meet in the Mediterranean Context; Conference Book of Abstracts; Universidade de Évora: Évora, Portugal, 2014; pp. 13-147.

75. Forestry Commission. Putting the Green in the Grey. Creating Sustainable Grey Infrastructure. A Guide for Developers, Planners, and Project Managers; Forestry Commission: Bristol, UK, 2009.

76. Segnestam, L. Indicators of Environment and Sustainable Development: Theories and Practical Experience; Environmental Economics Series 89; The World Bank Environment Department: Washington, DC, USA, 2002.

77. Escobedo, F.J.; Kroeger, T.; Wagner, J.E. Urban forests and pollution mitigation: Analyzing ecosystem services and disservices. Environ. Pollut. 2011, 159, 2078-2087. [CrossRef]

78. Mediterranean Experts on Climate and Environmental Change (MedECC). Risks Associated to Climate and Environmental Changes in the Mediterranean Region. A Preliminary Assessment by the MedECC Science-Policy Interface. Available online: https://ufmsecretariat.org/wp-content/uploads/2019/10/MedECC-Booklet_EN_WEB.pdf (accessed on 6 August 2021).

79. Maes, J.; Zulian, G.; Günther, S.; Thijssen, M.; Raynal, J. Enhancing Resilience of Urban Ecosystems through Green Infrastructure; Final Report, EUR 29630 EN.; Publications Office of the European Union: Luxembourg, 2019. [CrossRef]

80. Borelli, S.; Conigliaro, M.; Pineda, F. Urban Forests in the global Context. Unasylva 2018, 69, 3-10.

81. Martí, P.; Serrano-Estrada, L.; Nolasco-Cirugeda, A. Using locative social media and urban cartographies to identify and locate succesful urban plazas. Cities 2017, 64, 66-78. [CrossRef]

82. Oktay, D. Smart and Sustainable Urbanism with Identity in Mediterranean Cities. In Green Buildings and Renewable Energy. Innovative Renewable Energy; Sayigh, A., Ed.; Springer: Cham, Switzerland, 2020.

83. Cariñanos, P.; Salbitano, F.; Conigliaro, M. Foretst and Cities: Forests-Based Solutions in Urban Areas. Forèt Méditerranéennee 2019, 3, 261-268.

84. Cariñanos, P.; Casares-Porcel, M. Urban Green Zones and Related Pollen Allergy: A review. Some guidelines for designing spaces with low allergy impact. Landsc. Urban Plan. 2011, 101, 205-214. [CrossRef]

85. Ren, Y.; Qu, Z.; Du, Y.; Xu, R.; Ma, D.; Yang, G.; Shi, Y.; Fan, X.; Tani, A.; Guo, P.; et al. Air quality and health effects of biogenic volatile organic compounds emissions from urban green spaces and the mitigation strategies. Environ. Pollut. 2017, 230, 849-861. [CrossRef]

86. Grote, R.; Samson, R.; Alonso, R.; Amorim, J.H.; Cariñanos, P.; Churkina, G.; Fares, S.; Thiec, D.L.; Niinemets, Ü.; Mikkelsen, T.N.; et al. Functional traits of Urban trees: Air pollution mitigation potential. Front. Ecol. Environ. 2016, 14, 543-550. [CrossRef]

87. Manescu, C.R.; Dpbrescu, E.; Nujnoi, S.; Toma, F.; Petra, S. Toxic plants species in parks located in city centre of Bucharest. Scientific Papers. Series B. Horticulture 2019, 63, 529-534.

88. Constán-Navas, S.; Bonet, A.; Pastor, E.; Lledó, M.J. Long-term control of the invasive tree Ailanthus altissima: Insights from Mediterranean protected forests. For. Ecol. Manag. 2020, 260, 1058-1064. [CrossRef]

89. Abdelhamid, M.M.; Elfakharany, M.M. Improving urban park usability in developing countries: Case-study of Al-Shalalat Park in Alexandria. Eng. J. 2020, 59, 311-321. [CrossRef]

90. Jiménez-Delgado, A.; Lloret, J. Health, Wellebing and Sustainability in the Mediterranean City. Interdisciplinary Perspectives. Routledge Studies in Urbanism and the City; Taylor and Francis Group: Boca Raton, FL, USA, 2019.

91. Transnational Institute (Amsterdam) and Latin American Council of Social Sciences. Public Water and COVID-Dark Clouds and Silver Linnings; Municipal Service Project; McDonald, D.A., Sprouk, S.J., Chaves, D., Eds.; Transnational Institute (Amsterdam) and Latin American Council of Social Sciences: Amsterdam, The Netherlands, 2021. 
92. Ayala-Azcárraga, C.; Díaz, D.; Zambrano, L. Characteristics of urban parks and their relation to well-being. Landsc. Urban Plan. 2019, 189, 27-35. [CrossRef]

93. McComack, G.R.; Rpck, M.; Toohey, A.M.; Hignell, D. Characteristics of urban parks associated with park use and physical activity: A Review of qualitative research. Health Place 2010, 16, 712-726. [CrossRef] [PubMed]

94. Dempsey, N.; Burton, M. Defining place-keeping: The long-term management of public spaces. Urban For. Urban Green. 2012, 11, 11-20. [CrossRef]

95. Duinker, P.N.; Lehvävirta, S.; Busse Nielsen, A.; Toni, S.A. Urban woodlands, and their management. In Routledge Handbook of Urban Forestry; Ferrini, F., Konijnendijk, C.C., Fini, A., Eds.; Routledge, Taylor and Francis Group: Boca Raton, FL, USA, 2019.

96. Maruthaveeran, S.; van den Bosch, C.C.K. A socio-ecological exploration of fear of crime in urban green spaces. A systematic review. Urban For. Urban Green. 2014, 13, 1-18.

97. Tandogan, O.; ILhan, B.S. Fear of crime in public spaces: From the view of women living in cities. Procedia Eng. 2016, 161, 2011-2018. [CrossRef]

98. Toribio Marín, C. The fourfold Water Garden, a Renaissance Invention. Gard. Landsc. 2016, 4, 1-16. [CrossRef]

99. Pérez-Igualada, J. Water-sensitive strategies in the new urban parks in Valencia: The Agricultural Mediterranean paradigm as a pattern for landscape management and design. Int. J. Sustain. Dev. Plan. 2016, 9, 97-106. [CrossRef]

100. Hua, L.; Zhang, X.; Nie, Q.; Sun, F.; Tang, L. The impacts of the Expansion of Urban Impervious Surfaces on Urban Heat Islands in Coastal City in China. Sustainability 2020, 12, 475. [CrossRef]

101. AEMET-OECC. Cambio Climático: Calentamiento Global de $1.5^{\circ} \mathrm{C}$; Agencia Estatal de Meteorología y Oficina Española de Cambio Climático, Ministerio para la Transición Ecológica: Madrid, Spain, 2018.

102. Ferguson, B.K. Permeable pavements in Liveable, Sustainable Cities. CityGreen 2018, 5, 34-39. [CrossRef]

103. Good Gardening Practices in Barcelona. Conserving and Improving Biodiversity. Ayuntamiento de Barcelona. 2016. Available online: https:/ / ajuntament.barcelona.cat/ecologiaurbana/sites/default/files/Bones-practiques-jardineria-2016-ENG.pdf (accessed on 10 September 2021).

104. Jiménez-Alfaro, B.; Frischi, S.; Stolz, J.; Gálvez, C. Native plants for greening Mediterranean agroecosystems. Nat. Plants 2020, 6, 209-214. [CrossRef]

105. Nowak, D.J.; Heisler, G.M. Air Quality Effects of Urban Trees and Parks; Research Series; National Recreation and Park Association: Ashburn, VA, USA, 2010.

106. Li, G.; Wan, L.; Cui, M.; Wu, B.; Zhou, J. Influence of Canopy Interception and Rainfall Kinetic Energy on Soil under Forests. Forests 2019, 10, 509. [CrossRef]

107. Peel, M.C.; Finlayson, B.L.; McMahon, T.A. Updated world map of the Köppen-Geiger climate classification. Hydrol. Earth Syst. Sci. 2007, 11, 1633-1644. [CrossRef]

108. Pantovou, K.G.; Jacovides, C.P.; Nikolopoulo, G.K. Data on solar sunburning ultraviolet (UVB) radiation at an urban Mediterranean climate. Data Brief 2017, 11, 597-600. [CrossRef] [PubMed]

109. Li, X.; Ratti, C.; Seiferling, I. Quantifying the shade provision of street trees in urban landscape: A case study in Boston, USA, using Google Street view. Landsc. Urban Plan. 2018, 169, 81-91. [CrossRef]

110. Oliveira, S.; Vaz, T.; Andrade, H. Perception of thermal comfort by users of urban green areas in Lisbon. Finisterra 2014, 49, 113-131. [CrossRef] 